\title{
Water-Quality Trends in Suburban Houston, Texas, 1954-97, as Indicated by Sediment Cores From Lake Houston
}

Water-quality trends were assessed in Lake Houston using age-dated sediment cores. Sedi ments deposited in the lake contain a partialchemical signature of fuman activities in the water. shed. Over time, a water-quality fistory is recorded in the bottom sediments. Although the sediments in Lake Houston are clean compared to sediment-quality guidelines, increasing concentrations of mercury, zinc, and polycyclic aromatic fydrocarbons (PAHs) during the past several decades are evidence of the increasing human effect on water quality. The positive effects of regulation are indicated by decreases in concentrations of lead and $\mathcal{D} \mathcal{D}$.

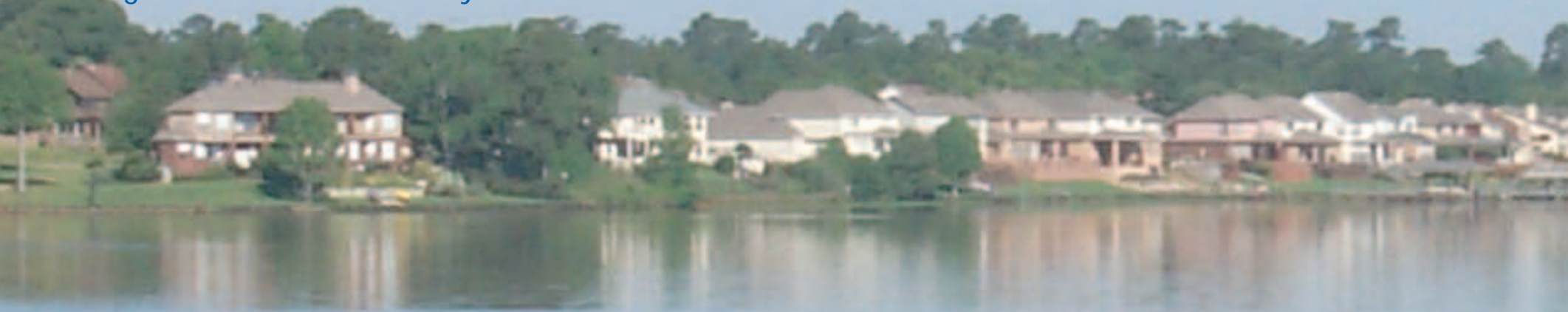

\section{As cities grow and urban sprawl} replaces rangeland, agricultural fields, and forests, water quality declines (Van Metre and others, 2000). Large numbers of people, cars and trucks, the presence of industries, and large amounts of impervious surface all contribute to the decline. Conversely, new regulations and other changes in human activities, for example, banning a pesticide or switching to unleaded gasoline, can result in improvements in water quality (Callender and Van Metre, 1997; Van Metre and others, 1997).

Many of the contaminants of concern in the environment are hydrophobic (literally "water fearing") and are, therefore, mostly attached to soils and sediments. Just because they are not dissolved in water, however, doesn't mean they are not of concern. In 2001 the Agency for Toxic Substances and Disease Registry and the U.S. Environmental Protection Agency (USEPA) published a priority list of hazardous substances (Agency for Toxic Substances and Disease Registry, 2001). Fifteen of the top 20 contaminants on the list are hydrophobic, including 4 trace elements and 11 organic contaminants.

One method for determining trends in hydrophobic contaminants is the chemical analysis of sediment cores. As sediments accumulate in lakes and bays, they create a partial historical record of water quality. The purpose of this study was to determine historical trends in the concentrations of selected hydrophobic contaminants in the Lake Houston watershed using sediment cores from the lake. The study was a cooperative effort between the U.S. Geological Survey (USGS) and the City of Houston. This report describes the methods of collecting and age-dating sediment cores and the resulting historical trends in hydrophobic contaminants. The report also briefly describes the results of tributary streambed sampling to help explain differences in sources of contaminants to the lake on the basis of land use. The report concludes with implications of the findings for the water quality of Lake Houston.

Lake Houston is a shallow reservoir on the San Jacinto River located about 25 miles northeast of Houston, Tex. It was constructed by the City of Houston in 1954 with a maximum capacity of 146,700 acre-feet and surface area of 19.1 square miles. The drainage area for Lake Houston (fig. 1) is 2,835 square miles. The upper end of the lake splits into two arms. Tributaries to the western arm include the West Fork San Jacinto River, Spring Creek, and Cypress Creek, together draining about 61 percent of the watershed. The eastern tributaries include the East Fork San Jacinto River, Peach Creek, Caney Creek, and Luce Bayou, draining about 33 percent of the watershed.

The area that drains to the eastern arm of the lake (fig. 1, area 1) is predominately forest land. The area that drains to the western arm of the lake through the West Fork San Jacinto River (fig. 1, area 2) also is largely forest land, although there is some agricultural land. The other tributaries to the western arm of the 

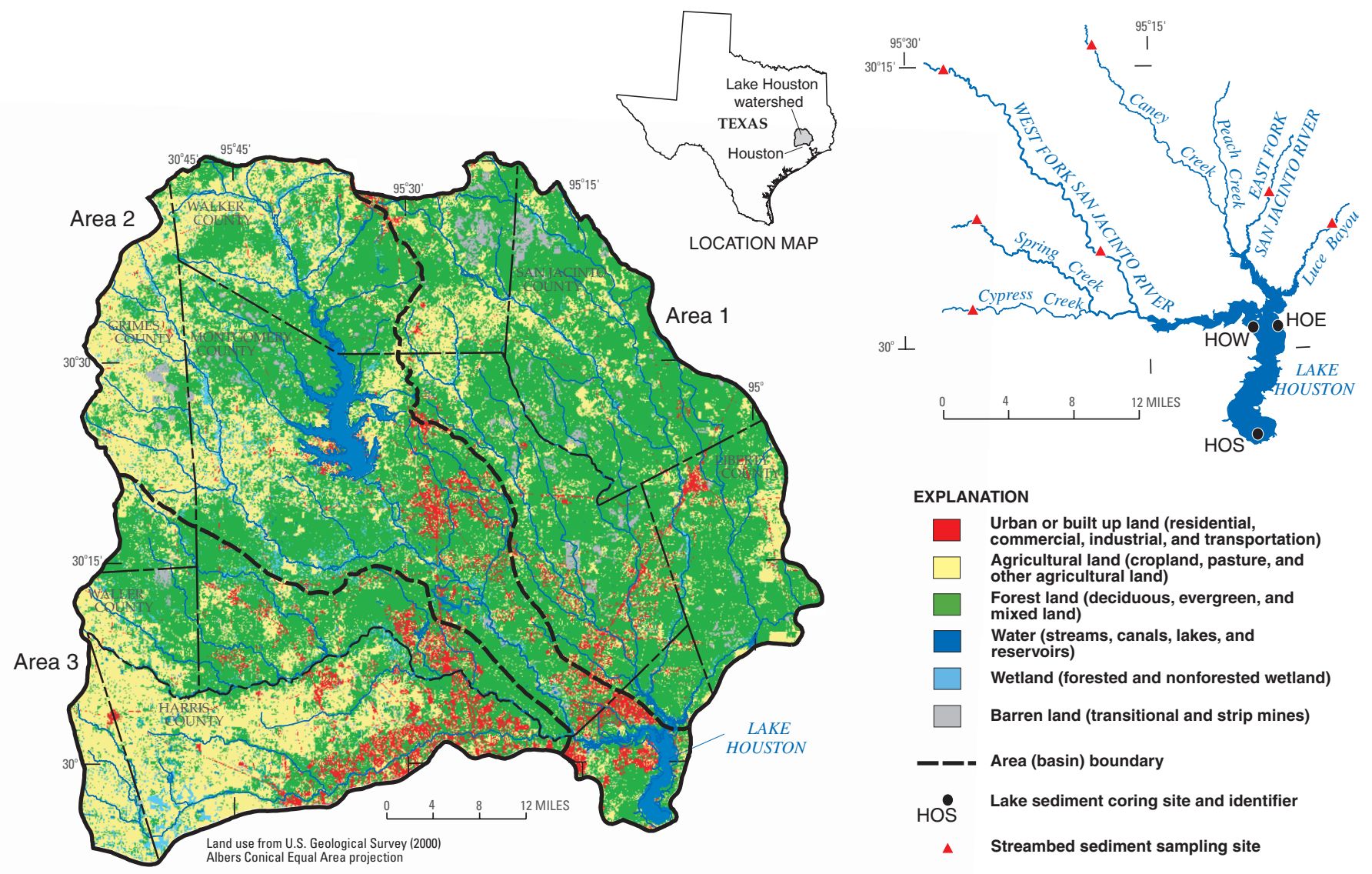

Figure 1. Lake Houston watershed showing land use (about 1992) and locations of lake sediment cores and streambed sediment samples.

lake, including Cypress and Spring Creeks, drain an area (fig. 1, area 3 ) that contains most of the agricultural and urban land in the watershed. Thus, there are differences in land use between the areas that drain to the eastern and western arms that could lead to differences in contaminant levels in the sediment.

Se dime nt cores were collected from three locations in Lake Houston in 1997: one site on each of the two major arms in the upper lake (HOW and HOE for the western and eastern arms, respectively) and one site in the lower part of the lake near the dam (HOS) (south site) (fig. 1). The HOW and HOE sites were selected to evaluate the effects on sediment quality of runoff from areas of different land use, and the HOS site was selected to evaluate the integrated effect of all land uses in the watershed.

Several gravity and box cores were collected at each of the three sampling sites. One gravity core from each site was split lengthwise and described visually on site. Other cores were extruded vertically, and slices were removed for chemical analysis. Analyses included cesium-137 $\left({ }^{137} \mathrm{Cs}\right)$ (HOE only), polychlorinated biphenyls (PCBs), PAHs, organochlorine pesticides, and major and trace elements.

The samples were analyzed by USGS laboratories using various methods. ${ }^{137} \mathrm{Cs}$ for age dating was measured by radioactive counting (similar to the method used by Callender and Robbins, 1993). Organic compounds were measured by gas chromatography/mass spectrometry (GC/MS) (Foreman and others, 1995; Furlong and others, 1996). Major and trace elements were meas- ured by inductively coupled plasma/atomic emission spectroscopy (ICP/AES) and graphite-furnace atomic adsorption (GFAA) (Fishman and Friedman, 1989).

Age - d ating of sediment cores was done using the prereservoir boundary (dated as 1954) and the sampling date in July 1997 as date markers. In reservoir sediment cores, sediment deposited after the lake formed is easy to distinguish from prereservoir soil. The gravity cores all penetrated to pre-reservoir

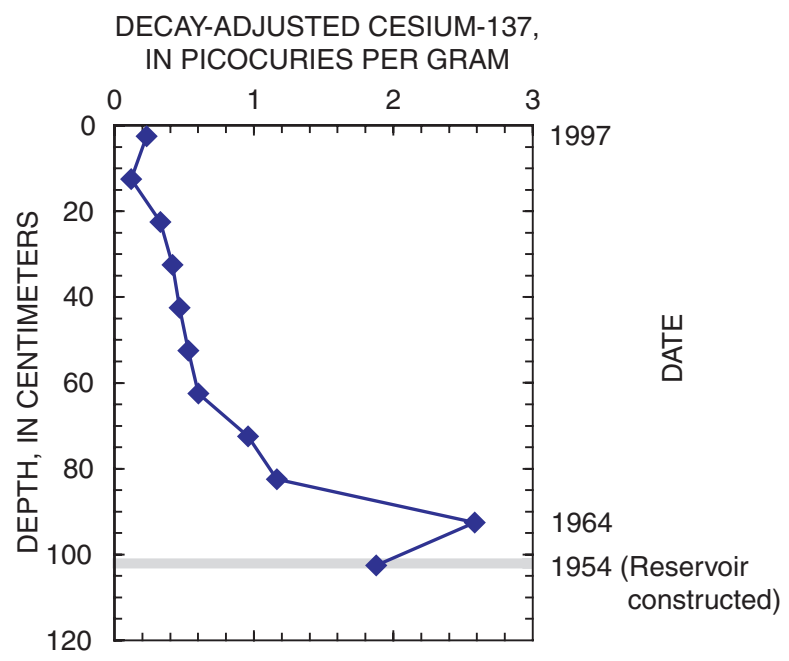

Figure 2. Cesium-137 profile in HOE core. 


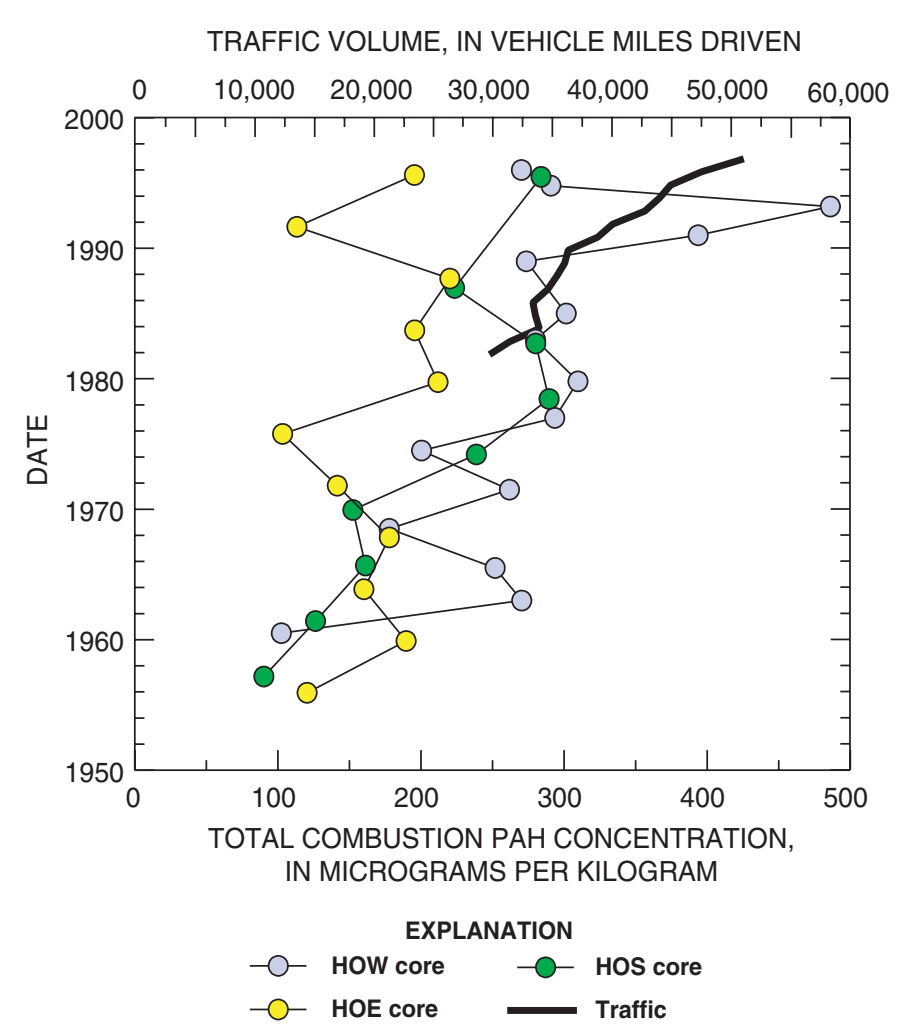

Figure 3. $\mathrm{PAH}$ trends in Lake Houston cores.

soils that, below Lake Houston, were relatively dry and contained sand and root hairs. Lake sediments were very soft, wet clays. Samples between the pre-reservoir surface and the top of the cores were assigned age dates assuming the sedimentation rate was constant. Dates assigned in this manner to the HOE core were corroborated by the ${ }^{137} \mathrm{Cs}$ profile (fig. 2). ${ }^{137} \mathrm{Cs}$ is a radionuclide released to the atmosphere by nuclear weapons testing. ${ }^{137} \mathrm{Cs}$ reached a peak concentration in the atmosphere during 1963-64. The ${ }^{137} \mathrm{Cs}$ profile measured in the HOE core has a peak in the lower part of the core. The date of 1964 assigned to this interval confirms that the sediment record extends back to when the reservoir was built in 1954 and indicates that sedimentation has been relatively constant over time.

Streambed sediment samples were collected from seven sites on the six largest tributaries (fig. 1) using the method of Shelton and Capel (1994). Streambed sediments were analyzed for PCBs, PAHs, and organochlorine pesticides using the methods described for core samples. These samples were collected to help explain differences in sources of these organic contaminants to the lake as a function of land use in the watershed.

\section{Trends}

$\mathscr{P C B s}$ were widely used in urban and industrial applications in the United States from the 1950s to the 1970s. They are highly resistant to chemical breakdown and were banned by the USEPA in the 1970s. PCBs were detected in small concentrations in the HOW and HOS cores (maximums of 6.5 and 8.8 micrograms per

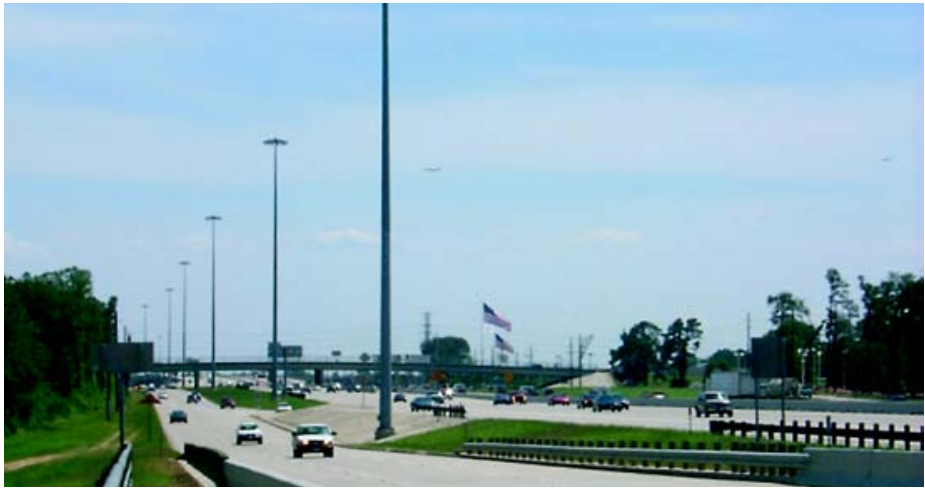

Highway scene in the Lake Houston watershed.

kilogram $[\mu \mathrm{g} / \mathrm{kg}]$, respectively). The detections were all in sediment deposited before about 1975. No PCBs were detected in the HOE core, reflecting the more rural, forested, eastern drainages.

$\mathcal{P A} \mathcal{H} s$ are produced by combustion of hydrocarbons, resulting in many urban sources including industrial and power plant emissions; car and truck exhaust; leaking motor oil; and wear of tires, asphalt roads, and roofs. PAHs are an environmental concern because they are toxic to aquatic life and because several are known or suspected carcinogens.

Total "combustion" PAH concentrations (the sum of nine representative PAH compounds [Barrick and Prahl, 1987]) increased from about 100 to about $300 \mu \mathrm{g} / \mathrm{kg}$ in the HOW and HOS cores during the past 40 years (fig. 3). These increases are statistically significant (Spearman's rank correlation test at a greater-than95-percent confidence level). The largest concentration was

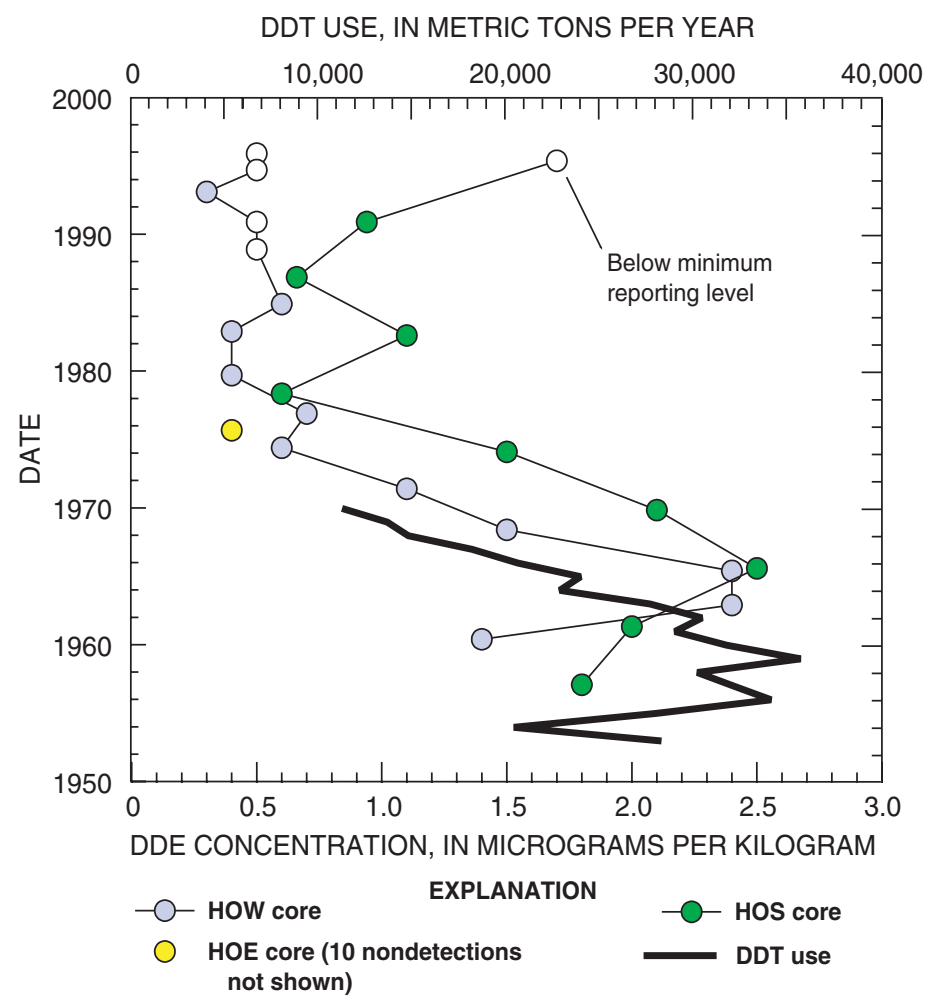

Figure 4. DDE trends in Lake Houston cores. 

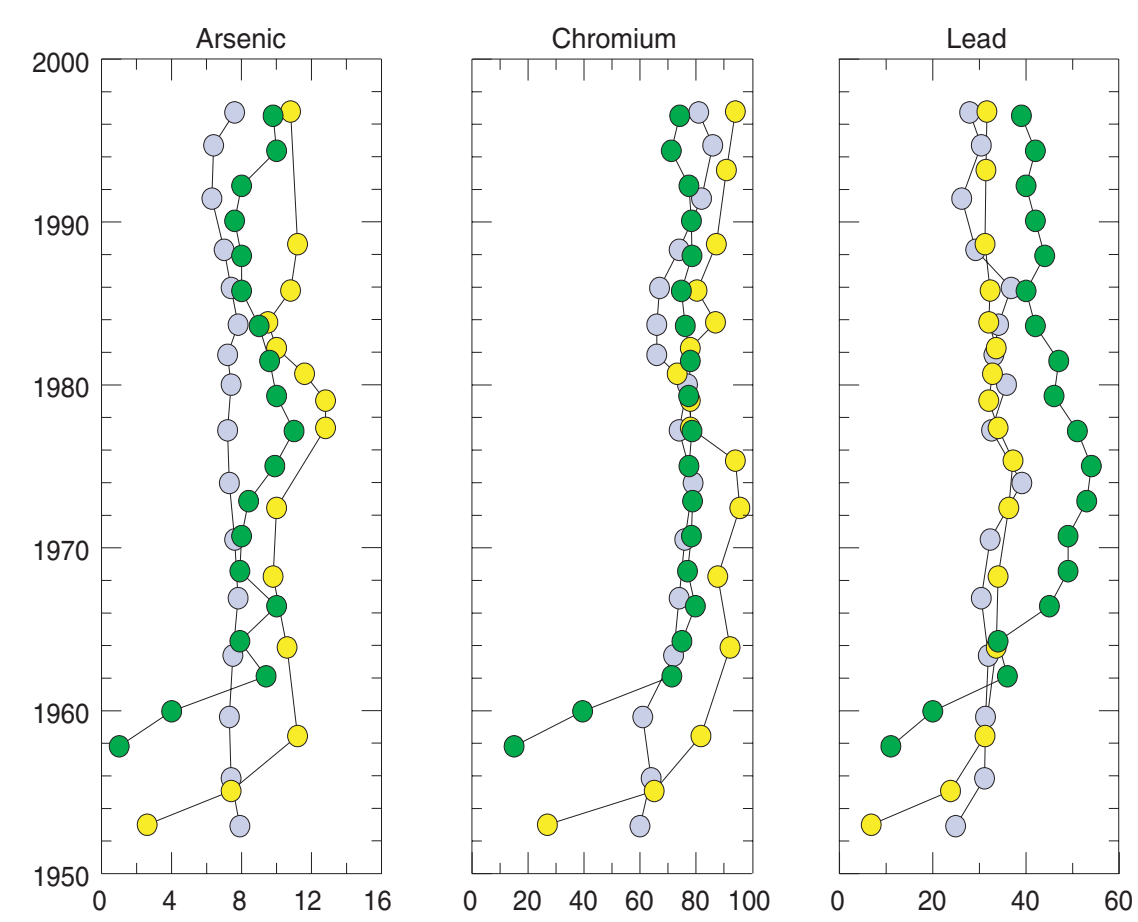

崖

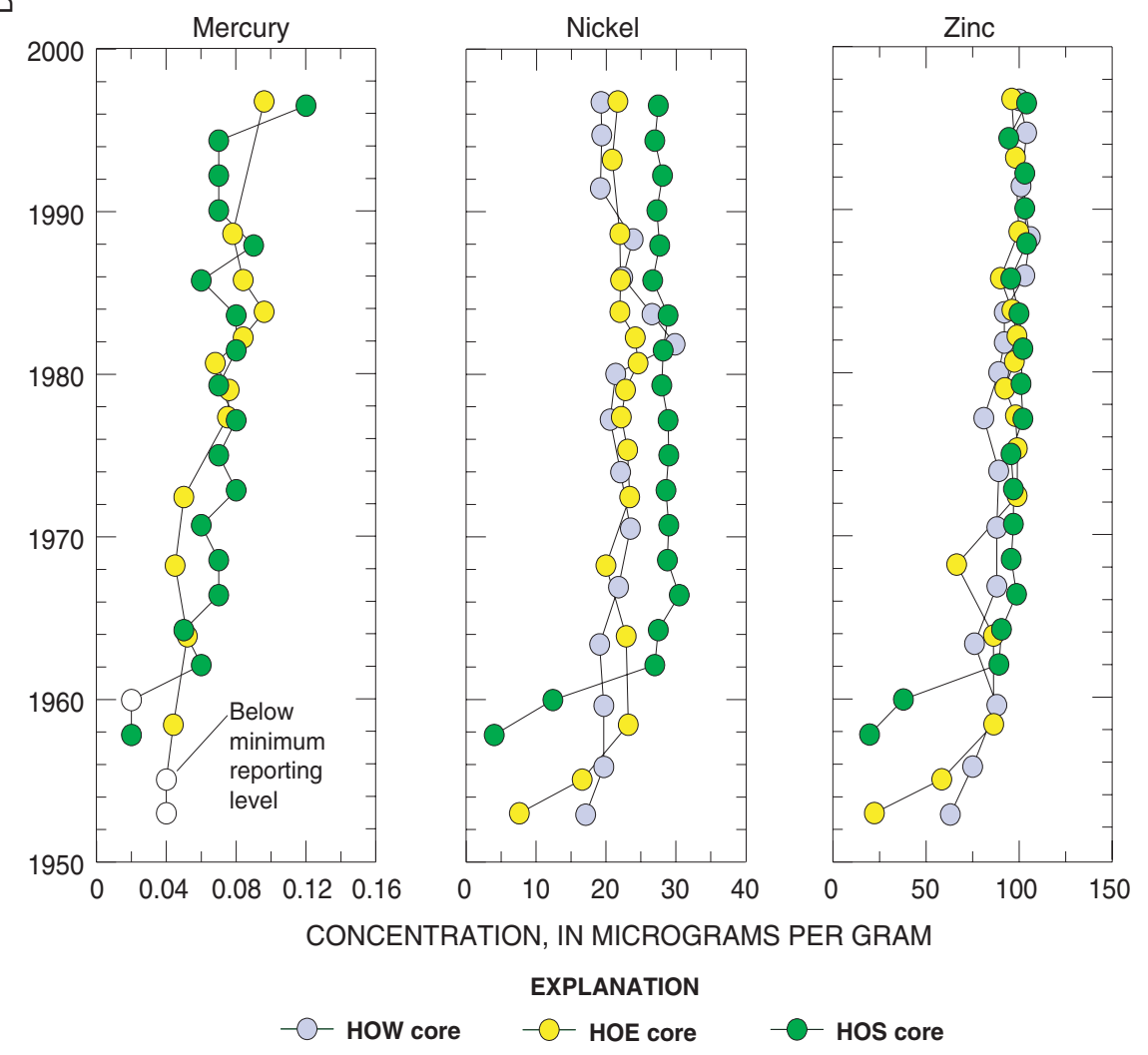

Figure 5. Trends in six trace elements in Lake Houston cores.

$486 \mu \mathrm{g} / \mathrm{kg}$ in a sample from the early 1990s in the HOW core. Both sites are influenced by urbanization that has occurred along the western tributaries to Lake Houston. In contrast, PAH concentrations in the HOE core range from about 100 to $220 \mu \mathrm{g} / \mathrm{kg}$ and do not show a statistical trend, probably reflecting the more rural setting of the eastern tributaries.
Van Metre and others (2000) reported increasing PAH concentrations in response to urbanization in many urban lakes and found a relation to changes in traffic volume (vehicle miles driven) in some of them. For comparison, traffic data for greater Houston since the early 1980s are shown in figure 3 (Schrank and Lomax, 1999). Although the PAH concentrations in the Lake Houston cores are still relatively small compared to most urban lakes (Van Metre and others, 2000), the increases in the HOW and HOS cores suggest urban growth is affecting sediment quality in the lake.

$\mathcal{D} \mathcal{D} \mathcal{T}$ use in the United States peaked in about 1960 (fig. 4) and was banned by the USEPA in the United States in 1972. DDT breaks down into DDE and DDD, which also are toxic and very resistant to further chemical breakdown. In Lake Houston, only one sample had detectable DDT, $0.5 \mu \mathrm{g} / \mathrm{kg}$ in a sample from the HOW core dated about 1963. DDD also was rarely detected, with reportable levels in only four samples. DDE, however, was detected in 9 of 10 samples from HOS and 11 of 15 samples from HOW, but only 1 of 11 from HOE. These differences reflect land-use differences between areas draining to the western and eastern tributaries and indicate historical urban and agricultural uses of DDT in areas draining to the western tributaries. DDE concentrations are very low compared with those of most urban lakes (Van Metre and others, 1997). Decreases since the 1960s in DDE in the HOW and HOS cores are statistically significant. DDE was not detected in the most recent sample from any of the three cores.

Trace e le me nt concentrations in core samples from Lake Houston are relatively stable over time, with the exception of modest variations in arsenic and lead and small increasing trends in mercury and zinc (fig. 5). The large "bulge" in lead concentrations in the HOS core in the 1970s matches the timing of elevated lead concentrations in cores from numerous urban lakes across the country caused by the use of leaded gasoline (Callender and Van Metre, 1997). Decreases in lead since 1975 are statistically significant in all three cores. Increasing trends in zinc since the late 1950 s also are significant in all three cores, and increasing trends in mercury are indicated at HOS and HOE. Mercury was not measured in the HOW core.

Concentrations of all six trace elements shown in figure 5 are much lower in some samples from the bottoms of the cores, which 


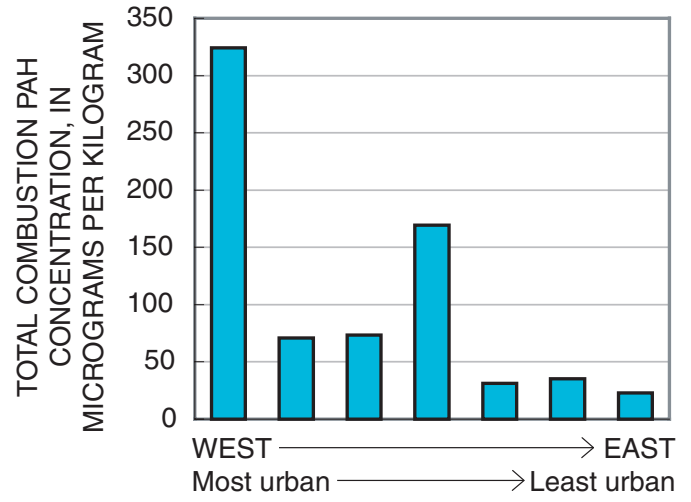

Figure 6. Total combustion PAH in streambed sediments from seven sites on the six largest tributaries to Lake Houston.

reflect concentrations in pre-reservoir soils, erosion of bank material soon after lake formation, or possibly some mixing of lake sediment and soils. These low-concentration samples were not included in the statistical trend testing.

Relations among cores relative to concentrations of these six elements fall into one of three patterns: (1) One side of the watershed (HOE core) has higher concentrations than the other (HOW core), and the main-lake core (HOS) has intermediate concentrations (arsenic and chromium); (2) both sides of the watershed (HOW and HOE cores) are similar, and the HOS core has higher concentrations (lead and nickel); and, (3) all the cores are similar (mercury and zinc).

Arsenic and chromium concentrations (pattern 1) in the HOE core are elevated relative to the HOW core. Concentrations in the HOS core are intermediate to the HOW and HOE cores, suggesting a mixing of inputs from the two arms. Both arsenic and chromium are used to preserve wood, and arsenic also is an ingredient in pesticides; however, we don't know if differences in the cores are caused by anthropogenic or natural sources.

Lead and nickel (fig. 5) show another type of relation among cores (pattern 2). Concentrations of these constituents are similar for the HOW and HOE cores and relatively greater in the HOS core. Greater concentrations in the HOS core could be the result of the relatively smaller grain size in the sediments there and (or) greater manganese and iron concentrations. Many metals bind to sediments proportionally to the available surface area of the sediments (a function of grain size) and bind to iron and manganese oxide coatings on sediments. quality guidelines ${ }^{1}$

Mercury and zinc concentrations (pattern 3) are similar and gradually increasing in all cores (fig. 5). Mercury concentrations approximately doubled from the 1950 s to the 1990 s, and zinc concentrations increased by about 15 percent. Anthropogenic mercury in lake sediments generally is assumed to come from atmospheric fallout, primarily from coal-fired plants and waste incineration. Elevated zinc concentrations in aquatic sediments occur in other urban streams and lakes in the United States (Callender and Rice, 2000) and could be caused partly by tire wear; car and truck tires contain zinc. Thus environmental zinc, like PAHs, is a general indicator of the effects of urbanization and traffic.

\section{Contaminants in Streambed Sediment}

The only organochlorine pesticide detected in the streambed sediment samples from the six tributaries is chlordane, and those detections are at low levels (maximum concentration $3.9 \mu \mathrm{g} / \mathrm{kg}$ ). No PCBs were detected. PAHs also were at relatively low levels, but did show a spatial pattern suggesting urban sources (fig. 6). Streams in figure 6 are sorted from west to east, which is approximately most to least urban. Total combustion PAH in the Cypress Creek sample was $324 \mu \mathrm{g} / \mathrm{kg}$, similar to concentrations in the HOW and HOS cores. In contrast, PAHs in the more rural eastern tributary sites are less than $50 \mu \mathrm{g} / \mathrm{kg}$.

\section{Implications for Water Quality}

One way to evaluate sediment quality is to compare concentrations to sediment-quality guidelines developed for the protection of aquatic life. The guidelines used here are the consensus-based sediment-quality guidelines for freshwater ecosystems developed and evaluated by MacDonald and others (2000). They were shown

Table 1. Comparison of maximum constituent concentrations in cores with sediment-

[TEC, threshold effect concentration; PEC, probable effect concentration; $\mu \mathrm{g} / \mathrm{kg}$, micrograms per kilogram; $\mu \mathrm{g} / \mathrm{g}$, micrograms per gram; --, not analyzed]

\begin{tabular}{|c|c|c|c|c|c|}
\hline \multirow{2}{*}{ Constituent } & \multicolumn{3}{|c|}{ Site } & \multicolumn{2}{|c|}{ Guideline $^{1}$} \\
\hline & HOW & HOE & HOS & TEC & PEC \\
\hline Total PAH ${ }^{2}(\mu \mathrm{g} / \mathrm{kg})$ & 800 & 600 & 840 & 1,610 & 22,800 \\
\hline $\mathrm{DDE}(\mu \mathrm{g} / \mathrm{kg})$ & 2.4 & .4 & 2.5 & 3.16 & 31.3 \\
\hline Arsenic $(\mu \mathrm{g} / \mathrm{g})$ & 7.9 & 13 & 11 & 9.79 & 33 \\
\hline Chromium $(\mu \mathrm{g} / \mathrm{g})$ & 86 & 96 & 80 & 43.4 & 111 \\
\hline Lead $(\mu \mathrm{g} / \mathrm{g})$ & 39 & 37 & 54 & 35.8 & 128 \\
\hline Mercury $(\mu \mathrm{g} / \mathrm{g})$ & -- & .096 & .12 & .18 & 1.06 \\
\hline Nickel $(\mu \mathrm{g} / \mathrm{g})$ & 30 & 25 & 30 & 22.7 & 48.6 \\
\hline Zinc $(\mu \mathrm{g} / \mathrm{g})$ & 106 & 100 & 104 & 121 & 459 \\
\hline
\end{tabular}


to be reliable predictors of toxicity or lack of toxicity in sediments from a variety of settings in North America.

None of the constituents measured in the Lake Houston cores exceeds the probable effect concentration (PEC), the level above which toxic effects are predicted (table 1). In several cases, trace elements exceed the threshold effect concentration (TEC), the level below which no toxic effect is predicted. Concentrations of these naturally occurring elements often are above the TEC, even in natural settings (P.C. Van Metre, U.S. Geological Survey, unpub. data, 2001). PAHs and DDE are at low levels, below the TEC. Thus, the Lake Houston sediments are relatively clean compared to the guidelines.

Low levels of contaminants compared to toxicity guidelines are not, however, the whole story at Lake Houston. Contaminant trends and spatial patterns in the cores and streambed sediments in relation to land use, historical uses of some contaminants, and environmental regulations indicate that

- Environmental regulations can be successful in eliminating or reducing the entry of contaminants into aquatic systems, as indicated by decreasing trends in PCBs, DDE, and lead.

- Urbanization is affecting water and sediment quality in the lake, as indicated by higher concentrations of PCBs, PAHs, and DDE in the HOW core than in the HOE core and by increasing trends in PAHs, mercury, and zinc.

\section{References}

Agency for Toxic Substances and Disease Registry, 2001, Top 20 hazardous substances-ATSDR/EPA priority list for 2001: Accessed January 23, 2002, at URL http://www.atsdr.cdc.gov/cxcx3.html

Barrick, R.C., and Prahl, F.G., 1987, Hydrocarbon geochemistry of the Puget Sound, Region III-Polycyclic aromatic hydrocarbons in sediments: Estuarine Coastal and Shelf Science, v. 25 , no. 2 , p. $175-192$.

Callender, Edward, and Rice, K.C., 2000, The urban environmental gradient-Anthropogenic influences on the spatial and temporal distributions of lead and zinc in sediments: Environmental Science and Technology, v. 34, no. 2, p. 232-238.

Callender, Edward, and Robbins, J.A., 1993, Transport and accumulation of radionuclides and stable elements in a Missouri River reservoir: Water Resources Research, v. 29, no. 6 , p. $1,787-1,804$.

Callender, Edward, and Van Metre, P.C., 1997, Reservoir sediment cores show U.S. lead declines: Environmental Science and Technology, v. 31, no. 9, p. 424A-428A.

Fishman, M.J., and Friedman, L.C., eds., 1989, Methods for determination of inorganic substances in water and fluvial sediments: U.S. Geological Survey Techniques of WaterResources Investigations, book 5, chap. A1, 545 p.

Foreman, W.T., Connor, B.F., Furlong, E.T., Vaught, D.G., and Merten, L.M., 1995, Methods of analysis by the U.S. Geological Survey National Water Quality Laboratory-Determination of organochlorine pesticides and polychlorinated biphenyls in bottom sediment by dual capillary-column gas chromatography with electron-capture detection: U.S. Geological Survey Open-File Report 95-140, 78 p.

Furlong, E.T., Vaught, D.G., Merten, L.M., Foreman, W.T., and Gates, P.M., 1996, Methods of analysis by the U.S. Geological Survey National Water Quality Laboratory-Determination of semivolatile organic compounds in bottom sediment by solvent extraction, gel permeation chromatographic fractionation, and capillary-column chromatography/mass spectrometry: U.S. Geological Survey Open-File Report 95-719, $67 \mathrm{p}$.

MacDonald D.D., Ingersoll, C.G., and Berger, T.A., 2000, Development and evaluation of consensus-based sediment quality guidelines for freshwater ecosystems: Archives of Environmental Contamination and Toxicology, v. 39, p. 20-31.

Schrank, D.L., and Lomax, T.J., 1999, The 1999 annual mobility report-Information for urban America: College Station, Tex., Texas Transportation Institute, Texas A\&M University, accessed July 21, 2000, at URL

http://mobility.tamu.edu/study/report.stm

Shelton, L.R., and Capel, P.D., 1994, Guidelines for collecting and processing samples of stream bed sediment for analysis of trace elements and organic contaminants for the National Water-Quality Assessment Program. U.S. Geological Survey Open-File Report 94-458, 20 p.

U.S. Geological Survey, 2000, National land cover data, Texas river basins: EROS Data Center, Multi-Resolution Land Characterization Project, version 09-26-2000.

Van Metre, P.C., Callender, Edward, and Fuller, C.C., 1997, Historical trends in organochlorine compounds in river basins identified using sediment cores from reservoirs: Environmental Science and Technology, v. 31, no. 8, p. 2,339-2,344.

Van Metre, P.C., Mahler, B.J., and Furlong, E.T., 2000, Urban sprawl leaves its PAH signature: Environmental Science and Technology, v. 34, no. 19, p. 4,064-4,070.

- P.C. Van Metre and D.A. Sneck-Fahrer

Any use of trade, product, or firm names is for descriptive purposes only and does not imply endorsement by the U.S. Government.

Information on technical reports and hydrologic data related to this study can be obtained from

Subdistrict Chief

U.S. Geological Survey

2320 LaBranch St., Rm. 1112

Houston, TX 77004
Phone: (713) 718-3655

FAX: (713) 718-3661

World Wide Web:

http://tx.usgs.gov/ 